URBAN BIRD ECOLOGY and CONSERVATION 


\title{
STUDIES IN AVIAN BIOLOGY
}

\author{
A Publication of the Cooper Ornithological Society
}

WWW.UCPRESS.EDU/GO/SAB

\begin{abstract}
Studies in Avian Biology is a series of works published by the Cooper Ornithological Society since 1978. Volumes in the series address current topics in ornithology and can be organized as monographs or multi-authored collections of chapters. Authors are invited to contact the series editor to discuss project proposals and guidelines for preparation of manuscripts.
\end{abstract}

\section{Series Editor}

Brett K. Sandercock, Kansas State University

\section{Editorial Board}

Frank R. Moore, University of Southern Mississippi John T. Rotenberry, University of California at Riverside Steven R. Beissinger, University of California at Berkeley

Katie M. Dugger, Oregon State University

Amanda D. Rodewald, Ohio State University Jeffrey F. Kelly, University of Oklahoma

See complete series list on page 325. 


\section{URBAN BIRD ECOLOGY and CONSERVATION}

Christopher A. Lepczyk and Paige S. Warren, Editors

Studies in Avian Biology No. 45

A PUBLICATION OF THE COOPER ORNITHOLOGICAL SOCIETY

University of California Press

Berkeley Los Angeles London 
University of California Press, one of the most distinguished university presses in the United States, enriches lives around the world by advancing scholarship in the humanities, social sciences, and natural sciences. Its activities are supported by the UC Press Foundation and by philanthropic contributions from individuals and institutions.

For more information, visit www.ucpress.edu.

Studies in Avian Biology no. 45

For e-book, see the UC Press website.

University of California Press

Berkeley and Los Angeles, California

University of California Press, Ltd. London, England

(C) 2012 by the Cooper Ornithological Society

Library of Congress Cataloging-in-Publication Data

Urban bird ecology and conservation / Christopher A. Lepczyk and Paige S. Warren, editors.

p. cm.-(Studies in avian biology; no. 45)

Includes bibliographical references and index.

ISBN 978-0-520-27309-2 (cloth : alk. paper)

1. Birds-Ecology. 2. Birds-Conservation. 3. Urban animals-Ecology.

4. Urban animals-Conservation. I. Lepczyk, Christopher A.

(Christopher Andrew), 1970- II. Warren, Paige S. (Paige Shannon)

QL698.95.U73 2012

$598-\mathrm{dc} 23$

Manufactured in the United States of America

$\begin{array}{llllllll}19 & 18 & 17 & 16 & 15 & 14 & 13 & 12\end{array}$

$\begin{array}{llllllllll}10 & 9 & 8 & 7 & 6 & 5 & 4 & 3 & 2 & 1\end{array}$

The paper used in this publication meets the minimum requirements of ANSI/NISO Z39.48-1992 (R 2002) (Permanence of Paper).

Cover illustration: Common Peafowl (Pavo cristatus), Kaneohe, Hawaii. Photo by Christopher A. Lepczyk.

\section{PERMISSION TO COPY}

The Cooper Ornithological Society hereby grants permission to copy chapters (in whole or in part) appearing in Studies in Avian Biology for personal use, or educational use within one's home institution, without payment, provided that the copied material bears the statement

“(C) 2012 The Cooper Ornithological Society"

and the full citation, including names of all authors. Authors may post copies of their chapters on their personal or institutional website, except that whole issues of Studies in Avian Biology may not be posted on websites.

Any use not specifically granted here, and any use of Studies in

Avian Biology articles or portions thereof for advertising, republication,

or commercial uses, requires prior consent from the series editor. 


\section{DEDICATION}

This volume is dedicated to Carl Marti,

who passed away before seeing the completion of this volume. 
